\title{
Analisis Pengaruh Doping Nitrogen Terhadap Sifat Kapasitif Superkapasitor Berbahan Graphene
}

\author{
Diah Ayu Safitri, Diah Susanti, Haniffudin Nurdiansyah. \\ Jurusan Teknik Material \& Metalurgi, Fakultas Teknologi Industri, Institut Teknologi Sepuluh Nopember (ITS) \\ Jl. Arief Rahman Hakim, Surabaya 60111 Indonesia \\ e-mail: santiche@mat-eng.its.ac.id
}

\begin{abstract}
Abstrak-Kebutuhan manusia akan barang elektronik semakin meningkat, sehingga meningkat pula kebutuhan akan media penyimpan listrik. Salah satu media penyimpan energy yaitu kapasitor. Electric Double Layer Capacitor (EDLC) merupakan superkapasitor yang memiliki waktu hidup yang lebih lama, rapat daya dan kecepatan charging-discharging tinggi. Graphene telah banyak dieksplorasi sebagai material untuk EDLC, salah satunya yaitu dengan pendopingan. Penelitian ini bertujuan untuk menganalisis pengaruh doping nitrogen terhadap struktur dan morfologi serta pengaruh doping nitrogen terhadap sifat kapasitif dari elektroda superkapasitor berbahan Graphene. Sintesis graphene diawali dari grafit yang dioksidasi menjadi grafit oksida dengan metode Hummer. Grafit oksida lalu direduksi dengan metode hydrotermal menjadi graphene. Penelitian ini memvariasikan doping nitrogen dengan penambahan $\mathrm{NH}_{4} \mathrm{OH} 0.1 \mathrm{ml}, 0.3 \mathrm{ml}$ dan $1 \mathrm{ml}$. Material yang disintesis ini dikarakterisasi menggunakan XRD(X-Ray Diffraction), SEM (Scanning Electron Microscopy), EDS (Energy Disspersive X-Ray analysis), FPP (Four Point Probe), dan FTIR (Fourier Transform Infrared Spectroscopu). Dari hasil karakterisasi menunjukkan bahwa material yang disintesis adalah graphene. Sifat kapasitif Elektroda diukur dengan melakukan uji Cyclic Voltametry $(\mathrm{CV})$ dengan rentang scan rate 5, 10, 50 dan $100 \mathrm{mV} / \mathrm{s}$. Dari hasil penelitian didapatkan doping nitrogen pada graphene yang paling optimal adalah dengan penambahan $\mathrm{NH}_{4} \mathrm{OH} 0.3 \mathrm{ml}$ yaitu $5.2 \%$ at dengan nilai kapasitansi sebesar $208.47 \mathrm{~F} / \mathrm{g}$.
\end{abstract}

Kata kunci : Graphene, kapasitansi, superkapasitor, doping, nitrogen.

\section{PENDAHULUAN}

$\mathrm{K}$ EBUTUHAN manusia akan barang elektronik semakin meningkat, sehingga meningkat pula kebutuhan akan media penyimpan listrik. Superkapasitor merupakan terobosan baru di dunia piranti penyimpan energi yang memiliki rapat daya yang besar, kapasitas penyimpanan muatan yang sangat besar, proses pengisian-pengosongan muatan yang cepat dan tahan lama jika dibandingkan dengan kapasitor biasa. Keunggulan tersebut menyebabkan superkapasitor telah digunakan secara luas dalam berbagai bidang seperti bidang teknologi digital, mesin listrik dan peralatan militer dan luar angkasa. Beberapa contoh material yang digunakan sebagai pengisi elektroda adalah karbon aktif, metal oksida, dan lain-lain.

Belakangan ini, graphene yang merupakan salah satu material karbon dengan ketebalan satu atom dalam struktur 2 dimensi, telah dikenal sebagai material yang ideal untuk penyimpan energi kimia. Hal ini disebabkan karena keunikan sifatnya antara lain memiliki konduktifitas elektrik yang tinggi, luas permukaan dan kesetimbangan kimia yang bagus [1]. Sifat selalu berhubungan dengan struktur dari material. Beberapa peneliti telah melakukan modifikasi sifat elektic dari graphene dengan mengontrol strukturnya, termasuk penyiapan carbon sheet dengan layer yang berbeda dan graphene dengan atau tanpa defek akibat dari metode sintesisnya [2].

Pada penelitian yang dilakukan Suresh B. Pada tahun 2016 [3], ditemukan bahwa ketika material Graphene dan Nitrogen dikombinasikan melalui proses pendopingan, maka akan menaikkan nilai kapasitansi dari superkapasitor. Penelitian Suresh dengan metode via supercritical fluid ini memiliki nilai kapasitansi sebesar 286 F/gram. Melihat nilai kapasitansi yang bagus ketika kedua Graphene dan nitrogen dikombinasikan, oleh karena itu perlu adanya penelitian lanjutan tentang kombinasi Graphene dengan Nitrogen. Sehingga dalam penelitian ini akan dilakukan doping nitrogen ke dalam Graphene untuk meningkatkan sifat kapasitif dan nilai kapasitansinya sebagai superkapasitor.

\section{METODE PENELITIAN}

\section{A. Sintesis Graphene dan N-Graphene}

Graphene disintesis dengan menggunakan metode hummer. Proses sintesis diawali dengan mengoksdasi grafit menjadi grafit oksida dengan menngunakan, $\mathrm{H}_{2} \mathrm{SO}_{4}$, $\mathrm{NaNO}_{3}$, dan $\mathrm{KMnO}_{4}$. Proses dilanjutkan dengan menstirring larutan selama 1 jam dan menambahakan $\mathrm{H}_{2} \mathrm{O}_{2}$ untuk menghilangkan kandungan $\mathrm{KMnO}_{4}$ sisa dalam larutan. Selanjutnya dilakukan proses pencucian menggunakan $\mathrm{HCl} 5 \%(0.01 \mathrm{M})$ untuk menghilangkan ionion logam yang tersisa apabila $\mathrm{pH}$ telah netral dan tidak terdapat endapan saat titrasi $\mathrm{BaCl}_{2}$ maka dilanjutkan proses drying pada temperatur $110^{\circ} \mathrm{C}$ selama 12 jam untuk memperoleh grafit oksida [4].

Grafit oksida disintesis dengan cara direduksi agar didapatkan Graphene. Pembuatan dimulai dengan cara melarutkan grafit oksida dengan aquades dan proses ultrasonikasi selama 90 menit agar didapatkan larutan yang homogen. Selanjutnya dilakukan proses hydrotermal untuk mendapatkan Graphene. Untuk pembuatan $\mathrm{N}$-Graphene larutan grafit oksida ditambah $\mathrm{NH}_{4} \mathrm{OH}$ dengan variasi 0.1 $\mathrm{ml}, 0.3 \mathrm{ml}$ dan $1 \mathrm{ml}$ setelah diultrasonikasi kemudaian distring selama 1 jam. Lembaran atau serbuk hasil hydrotermal dilakukan pencucian menggunakan aquades beberapa kali kemudian didrying dengan temperatur $80^{\circ} \mathrm{C}$ selama 12 jam.

\section{B. Pembuatan Elektroda}

Graphene dan aquades dicampur dengan perbandingan 1 $\mathrm{mg}$ : $1 \mathrm{ml}$. Kemudian diaduk menggunakan mesin stirer dengan kecepatan $300 \mathrm{rpm}$ selama 1 jam sampai terlihat larutan telah berwarna hitam dan material di dalamnya telah hancur. Kemudian larutan yang telah berisi Graphene digunakan untuk didepositkan ke dalam elektroda Nickel Foam dengan menggunakan ultrasonikasi selama 30 menit. 
Baik Nickel Foam dan Graphene setelah proses ultrasonikasi mengalami proses pengeringan, dengan proses drying di dalam muffle furnace pada $\mathrm{T}=110^{\circ} \mathrm{C}$ selama 12 jam. Setelah kering, spesimen di kompaksi agar material yang didepositkan tidak rontok. Sedangkan. Nickel foam lalu ditimbang sekali lagi untuk mengetahui massa Graphene yang terdeposit kedalam pori-pori nickel foam.

\section{Karakterisasi Material}

Pengamatan struktur grafit, grafit oksida, rGO dan NrGO dilakukan menggunakan XRD. Sampel grafit oksida berbentuk lembaran sedangkan Graphene berbentuk serbuk. Pengamatan difraksi sinar $\mathrm{x}$ dilakukan pada sudut $2 \theta=5^{\circ}$ $90^{\circ}$ dengan $\lambda \mathrm{Cu}-\mathrm{K} \alpha=1.54060 \AA$. Pengamatan morfologi dilakukan menggunakan instrumen SEM Inspect S50 dan pengamatan gugus fungsi menggunakan FTIR. Sedangkan untuk menentukan konduktifitas listrik Graphene dilakukan pengujian FPP. Pengujian untuk mengetahui nilai kapasitansi juga dilakukan dengan menggunakan instrumen AUTOLAB PG STAT 302 METHROM.

\section{HASIL DAN DISKUSI}

\section{A. Hasil Pengujian XRD}

Dari Gambar 1 dapat diketahui bahwa terdapat perbedaan posisi puncak pada sampel grafit, grafit oksida, dan graphene. Pada sampel grafit terdapat puncak (002) pada posisi $2 \theta=26.53^{\circ}$ dengan nilai dari $\mathrm{d}_{\text {spacing }}$ sebesar 3.36 $\dot{A}$ dengan bentuk puncak yang tajam dan intensitas yang tinggi. Hasil XRD pada grafit tersebut menunjukkan bahwa sifat kristalinitas grafit sangat baik. Setelah proses oksidasi pada grafit maka grafit berubah menjadi grafit oksida. Puncak dari grafit oksida berbeda dengan grafit yaitu berubah menjadi puncak (001) pada posisi $2 \theta=12.21^{0}$ dengan nilai $\mathrm{d}_{\text {spacing }}$ yang lebih besar menjadi $7.33 \dot{\mathrm{A}}$ dan intensitas yang lebih rendah.

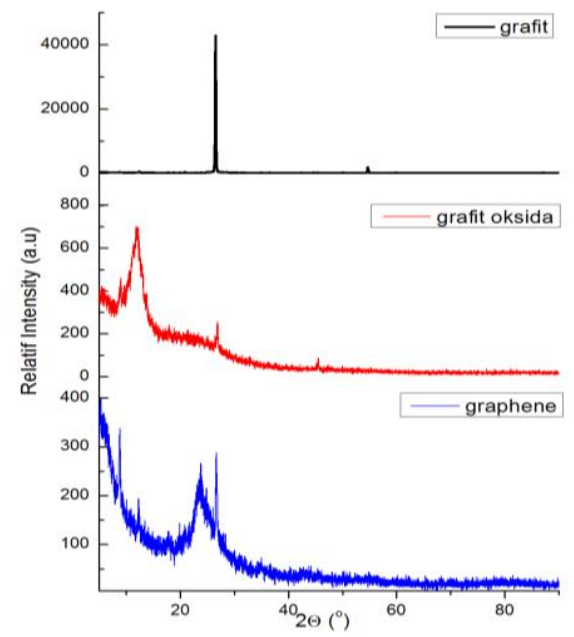

Gambar 1. Pola XRD pada grafit, grafit oksida, dan Graphene

Perubahan posisi puncak, nilai $\mathrm{d}_{\text {spacing }}$ dan intensitas dipengaruhi oleh gugus-gugus fungsional oksigen yang diakibatkan oleh proses oksidasi dalam material grafit dimana gugus-gugus oksigen membentuk lapisan atom hidrofilik yang menjadikan grafit oksida mudah larut dalam air [5]. Pada hasil XRD grafit oksida masih terdapat grafit pada posisi $2 \theta=26.9^{\circ}$. Gaphene mempunyai profil peak yang lebar pada posisi $\sim 23-24^{\circ}$. Adapun hasil XRD dari graphene berada pada puncak (002) posisi $2 \theta=23.89^{\circ}$ dengan nilai $\mathrm{d}_{\text {spacing }}=3.72 \dot{\mathrm{A}}$. Nilai $\mathrm{d}$-spacing yang menjadi lebih kecil menunjukkan bahwa grafit oksida telah tereduksi menjadi Graphene, selain itu nilai d-spacing Graphene yang lebih besar daripada grafit mengindikasikan bahwa telah terjadi pengelupasan lapisan grafit menjadi single layer Graphene [6].

Tabel 1.

Nilai d-spacing grafit, grafit oksida, Graphene

\begin{tabular}{ccc}
\hline \hline Sampel & $\mathbf{2 \theta}\left({ }^{\circ}\right)$ & $\boldsymbol{d}$-spacing $(\mathbf{\AA})$ \\
\hline Grafit & 26.53 & 3.36 \\
Grafit oksida & 12.21 & 7.33 \\
Graphene & 23.89 & 3.72 \\
\hline \hline
\end{tabular}

Pengujian XRD juga dilakukan terhadap N-Graphene, hal ini dilakukan untuk mengetahui perubahan struktur pada Graphene dengan didoping nitrogen.

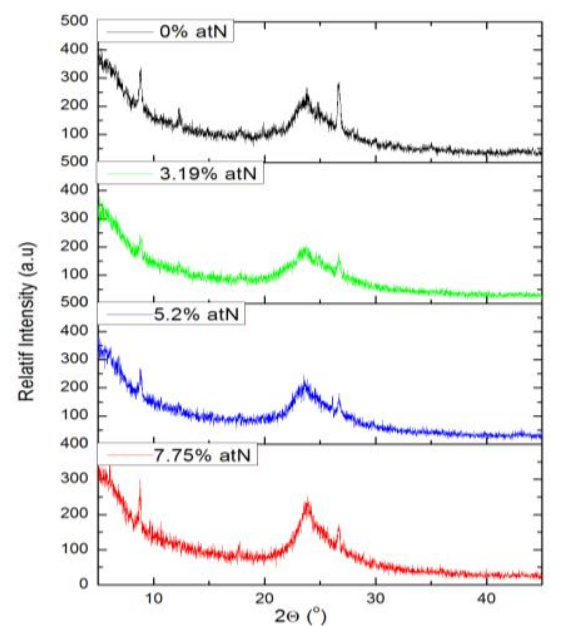

Gambar 2. Pola XRD pada Graphene/N-Graphene

Dari tabel 2, dapat dilihat terdapat pergeseran puncak untuk masing-masing nilai doping. Pada ketiga peak secara umum pergeseran terjadi ke derajat yang lebih rendah saat terjadi nilai doping. Berdasarkan persamaan Bragg $\mathrm{d}_{\text {spacing }}$ dari N-graphen menjadi lebih besar dengan ditambahnya doping atom nitrogen, $\mathrm{d}_{\text {spacing }}$ yang bertambah besar dikarenakan keberadaan atom nitrogen pada graphene memiliki jari-jari atom yang lebih besar dari carbon sehingga atom nitrogen telah berhasil didoping pada graphene[7].

Tabel 2.

Nilai d-spacing dan D Graphene/N-Graphene

\begin{tabular}{ccccc}
\hline \hline \%at $\mathbf{N}$ & $\mathbf{2 \theta}\left(^{\mathbf{0}}\right)$ & $\mathbf{d}_{\text {spacing }}(\mathbf{\AA})$ & $\begin{array}{c}\text { FWHM } \\
(\mathbf{r a d})\end{array}$ & $\mathbf{D}(\mathbf{n m})$ \\
\hline 0 & 23.89 & 3.72 & 0.0035 & 404.69 \\
3.19 & 23.72 & 3.73 & 0.0046 & 303.44 \\
5.2 & 23.77 & 3.74 & 0.0046 & 303.47 \\
7.75 & 23.79 & 3.75 & 0.0069 & 203.06 \\
\hline \hline
\end{tabular}

Pada grafik juga terlihat adanya perubahan FWHM (broadening) pada graphene akibat dari pertambahan nilai doping. Peak broadening ini dapat disebabkan oleh beberapa indikasi seperti perubahan kristal size. Untuk itu dilakukan analisis nilai kristal size rata-rata (D) pada graphene dan $\mathrm{N}$ - graphene dengan menggunakan persamaan Scherrer pada Persamaan 1 berikut. [7] 


$$
\mathrm{D}=\frac{\mathrm{ka}}{\beta \cos \theta}
$$

Dimana:

D : Ukura Kristal

$\lambda$ : Panjang gelombang $\mathrm{Cu}-\mathrm{K} \alpha(1.54060 \AA)$

B : FWHM (rad)

$\mathrm{K}$ : konstanta Scherrer dengan nilai 0.9

Nilai crystal size tertinggi terdapat pada graphene yang tidak diberikan doping dengan nilai $404.69 \mathrm{~nm}$, sementara yang terendah adalah graphene dengan doping $7.75 \%$ yaitu $203.06 \mathrm{~nm}$. Dari tabel tersebut, semakin banyak komposisi doping maka nilai crystal size akan semakin turun, penurunan crystal size ini dapat disebabkan oleh adanya defect akibat doping nitrogen. [9]

\section{B. Hasil Pengujian SEM}

Pengujian SEM dilakukan pada sampel grafit, grafit oksida, graphene, dan elektroda nickel foam-graphene ( $\mathrm{Ni}$ graphene) dengan variasi penambahan $\mathrm{NH}_{4} \mathrm{OH} 0.1 \mathrm{ml}, 0.3$ $\mathrm{ml}$ dan $1 \mathrm{ml}$ untuk membentuk $\mathrm{N}$-graphene. Alat yang digunakan dalam pengujian SEM yaitu INSPECT S50.
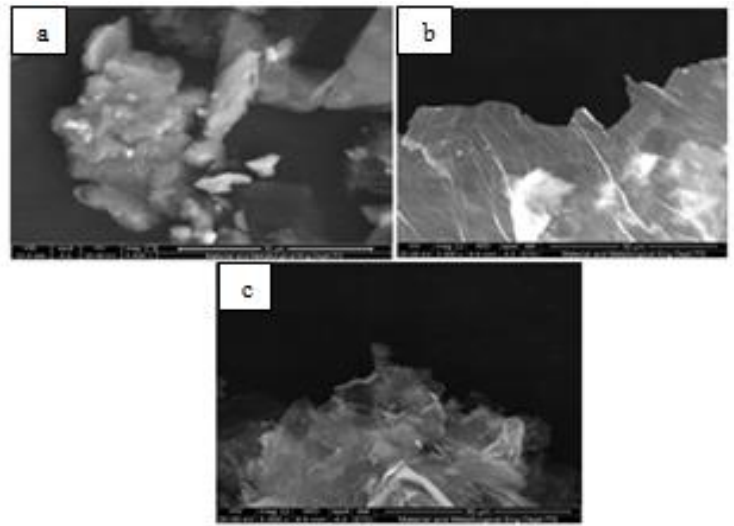

Gambar 3. Hasil SEM 5.000x (a) grafit, (b) grafit oksida, (c) Graphene tanpa doping

Pengujian SEM dilakukan untuk mengetahui morfologi permukaan dari sampel-sampel tersebut. Pada Gambar 3 ditunjukkan perbedaan permukaan morfologi dari sampel grafit, grafit oksida, dan graphene.

Berdasarkan Gambar 3a terlihat bahwa grafit memiliki morfologi dengan bentuk serupa serpihan atau flakes yang ukurannya kecil, menyebar, dan tidak beraturan. Setelah grafit mengalami oksidasi menjadi grafit oksida, maka morfologi yang terjadi menjadi lembaran-lembaran berlapis sehingga terlihat tebal seperti yang ditunjukkan Gambar 3b Kemudian grafit oksida mengalami reduksi menjadi graphene. Pada Gambar 3c terlihat lembaran-lembaran sangat tipis dari graphene yang terbentuk akibat pelupasan (chemical exfoliation) grafit oksida.

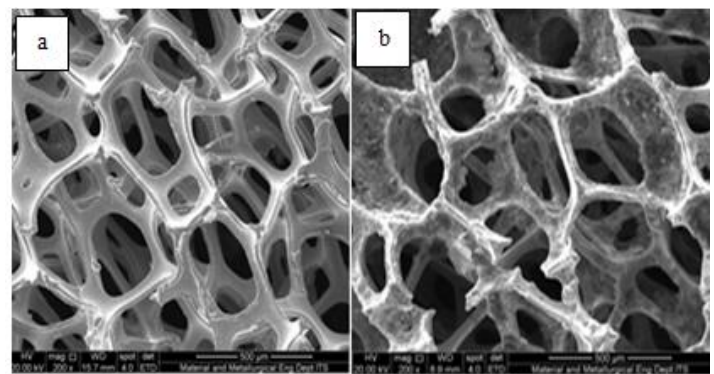

Gambar 4. Hasil SEM perbesaran 200x a) nickel foam b) nickel foam terdeposit graphene
Gambar 4a menunjukkan SEM image dari Nickel Foam polos dengan bentuk seperti network atau sponge. Dengan bentuk seperti jaring, Nickel Foam yang berfungsi sebagai pengumpul arus akan memberikan akses yang lebih mudah bagi elektrolit serta meningkatkan luas area kontak akibat strukturnya yang berupa porous. Pada Gambar 4b nampak bahwa Graphene telah berhasil di depositkan. Terlihat pula bahwa Graphene yang berupa lembaran-lembaran tipis mengisi atau menutupi lubang yang ada di Nickel Foam.

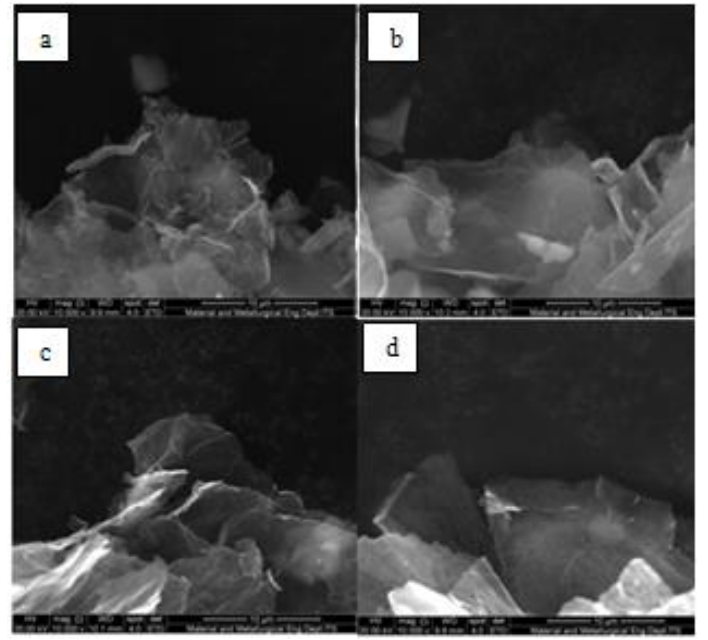

Gambar 5. Hasil SEM perbesaran 10.000x a) Graphene tanpa doping; NGraphene dengan penambahan $\mathrm{NH}_{4} \mathrm{OH}$ b) $0.1 \mathrm{ml} \mathrm{c)} 0.3 \mathrm{ml}$ d) $1 \mathrm{ml}$

Gambar 5 menunjukkan morfologi graphene hasil doping Nitrogen dengan penambahan $\mathrm{NH}_{4} \mathrm{OH} 0.1 \mathrm{ml}, 0.3$ $\mathrm{ml}$ dan $1 \mathrm{ml}$. Dari semua hasil tersebut, dapat kita lihat bahwa sampel graphene mempunyai bentuk morfologi yang hampir sama, yaitu berupa lembaran transparan tipis, yang terdiri dari beberapa layer graphene yang menumpuk sehingga terlihat lebih tebal, kadang juga terlihat adanya single layer. Pengamatan morfologi untuk graphene dengan doping nitrogen terlihat sama dan sulit untuk dibedakan [9].
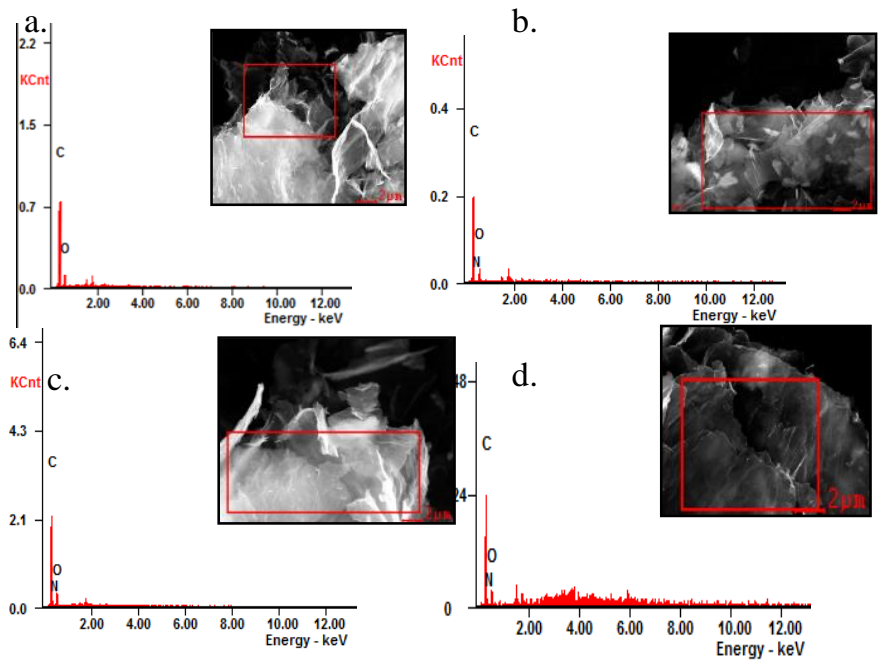

Gambar 6. Hasil EDS a) Graphene tanpa doping; N- Graphene dengan penambahan $\mathrm{NH}_{4} \mathrm{OH} \mathrm{b}$ ) $\left.\left.0.1 \mathrm{ml} \mathrm{c}\right) 0.3 \mathrm{ml} \mathrm{d}\right) 1 \mathrm{ml}$

Dari hasil pengujian EDS, dapat diketahuui bahwa graphene doping nitrogen dengan penambahan $\mathrm{NH}_{4} \mathrm{OH} 0.1$ $\mathrm{ml}$ mengandung atom nitrogen sebanyak $3.19 \%$, penambahan $\mathrm{NH}_{4} \mathrm{OH} 0.3 \mathrm{ml}$ mengandung atom nitrogen 
sebanyak 5.2\%, dan penambahan $\mathrm{NH}_{4} \mathrm{OH} 1 \mathrm{ml}$ mengandung atom nitrogen sebanyak $7.75 \%$

\section{Hasil Pengujian FTIR}

Pengujian FTIR dilakukan terhadap graphene dan Ngraphene, untuk mengetahui jenis ikatan apa saja yang ada di dalamnya, dan juga untuk membedakan antara graphene dan N-Graphene.

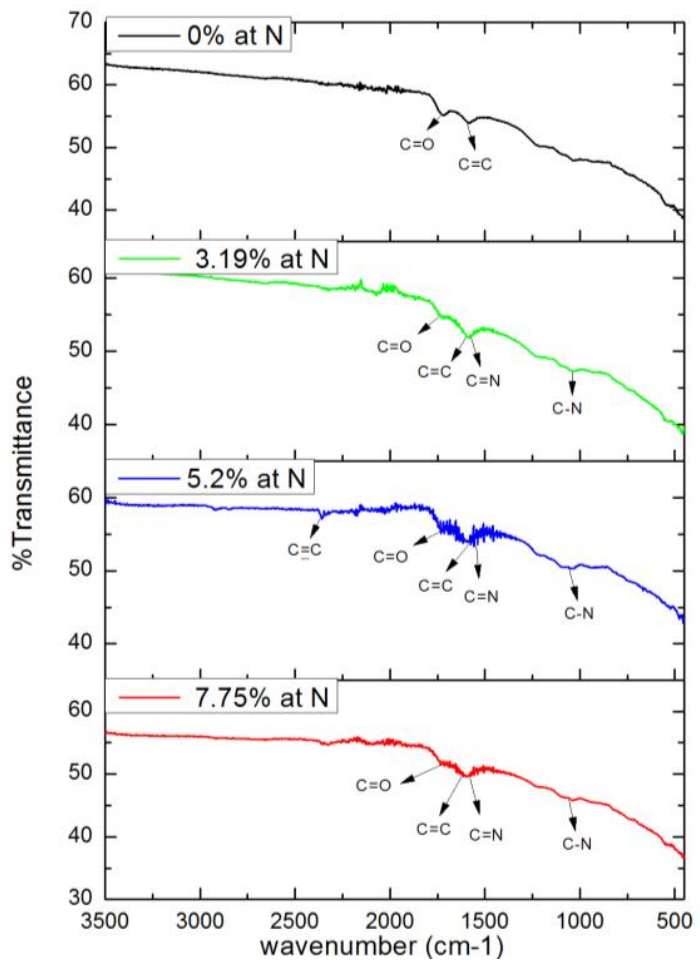

Gambar 7. Pola FTIR graphene, graphene dengan penambahan $\mathrm{NH} 4 \mathrm{OH}$ $0.1 \mathrm{ml}, 0.3 \mathrm{ml}$ dan $1 \mathrm{ml}$.

Dari Gambar 7 dapat dilihat bahwa pada graphene terdapat gugus $\mathrm{C}=\mathrm{C}\left(1587.34 \mathrm{~cm}^{-1}\right) \quad$ dan $\mathrm{C}=\mathrm{O}\left(1717.15 \mathrm{~cm}^{-}\right.$ $\left.{ }^{1}\right)$. Untuk graphene dengan penambahan $\mathrm{NH}_{4} \mathrm{OH} 0.1 \mathrm{ml}$ awalnya yang hanya terdapat gugus $\mathrm{C}=\mathrm{C}$ dan $\mathrm{C}=\mathrm{O}$ bertambah dengan adanya gugus $\mathrm{C}=\mathrm{N}\left(2356.73 \mathrm{~cm}^{-1}\right)$ dan $\mathrm{C}-\mathrm{N}\left(1083.25 \mathrm{~cm}^{-1}\right)$. Pada graphene dengan penambahan $\mathrm{NH}_{4} \mathrm{OH} 0.3 \mathrm{ml}$ terdapat gugus fungsi $\mathrm{C}=\mathrm{C}, \mathrm{C}-\mathrm{N}, \mathrm{C}=\mathrm{N}$ dan $\mathrm{C}=\mathrm{O}$. Graphene dengan penambahan $\mathrm{NH}_{4} \mathrm{OH} 1 \mathrm{ml}$ memiliki gugus fungsi yang sama dengan graphene yang ditambahkan $\mathrm{NH}_{4} \mathrm{OH}$ yang lain yaitu terdapat gugus $\mathrm{C}=\mathrm{C}$, $\mathrm{C}-\mathrm{N}, \mathrm{C}=\mathrm{N}$, dan $\mathrm{C}=\mathrm{O}$. Adanya gugus $\mathrm{C}=\mathrm{N}$ pada setiap graphene yang ditambahkan $\mathrm{NH}_{4} \mathrm{OH}$ menunjukan bahwa graphene telah berhasil didoping dengan atom nitrogen [10].

\section{Hasil Pengujian FPP}

Berdasarkan tabel, dapat diketahui perbandingan konduktivitas graphene dan $\mathrm{N}$ - graphene. Dapat dilihat bahwa dangan penambahan doping nitrogen dapat meningkatkan konduktifitas tetapi untuk graphene dengan $7.75 \%$ at $\mathrm{N}$ memiliki nilai konduktifitas yang lebih kecil dibanding dengan yang lainya hal ini dikarenakan keheteroatoman yang besar, jumlah atom nitrogen yang terlalu banyak pada graphene dapat mengurangi efisiensi transpor elektronya yang mengakibatkan nilai konduktifitas listrik menurun.[12]
Tabel 3.

Hasil perhitungan uji FPP

\begin{tabular}{ccccc}
\hline \hline Sampel & $\begin{array}{c}\text { Tebal } \\
(\mathbf{c m})\end{array}$ & $\begin{array}{c}\text { Hambatan } \\
(\boldsymbol{\Omega})\end{array}$ & $\begin{array}{c}\text { Resistivitas } \\
(\boldsymbol{\Omega} \mathbf{~ c m})\end{array}$ & $\begin{array}{c}\text { Konduktiv } \\
\text { itas Listrik } \\
(\mathbf{S} / \mathbf{c m})\end{array}$ \\
\hline $\begin{array}{c}\text { Graphene } \\
\text { N- Graphene } \\
\text { 3.19\% }\end{array}$ & 0.015 & $4.3 \times 10^{3}$ & 294.18 & 0.0034 \\
N- Graphene & 0.015 & $4.1 \times 10^{3}$ & 256.41 & 0.0039 \\
$\begin{array}{c}5.2 \% \\
\text { N- Graphene } \\
7.75 \%\end{array}$ & 0.015 & $4.12 \times 10^{3}$ & 243.90 & 0.0041 \\
\hline \hline
\end{tabular}

\section{E. Hasil Pengujian Cyclic Voltametry}
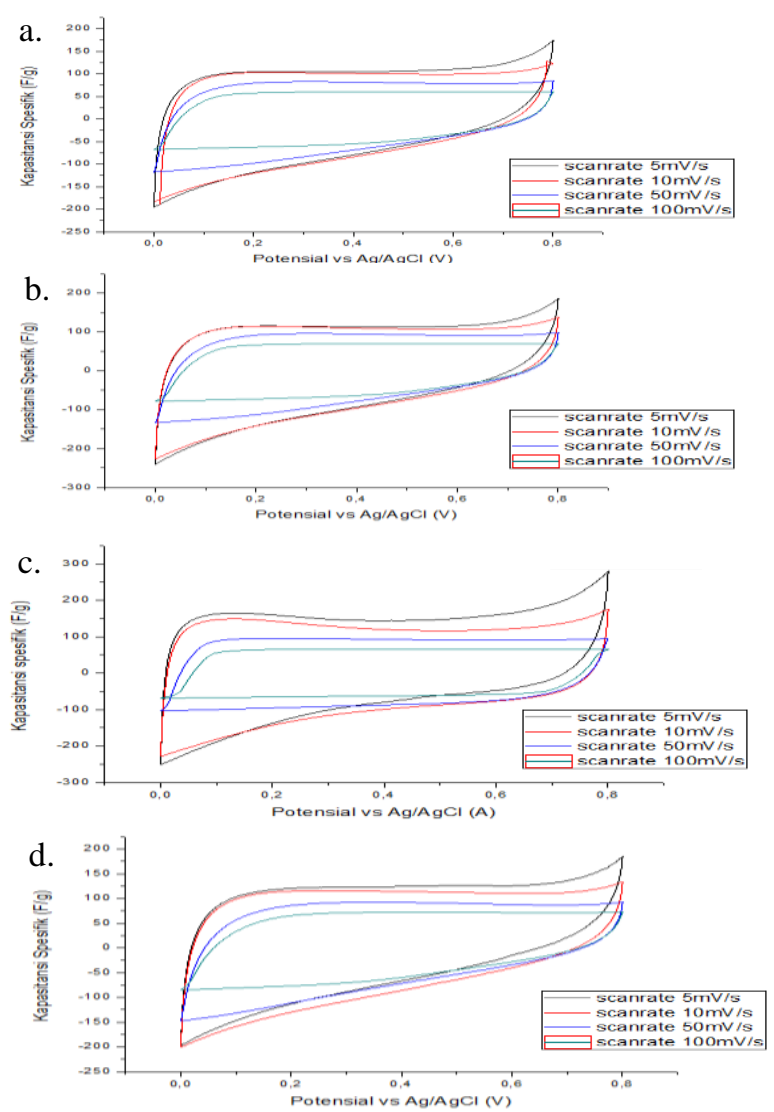

Gambar 8. Perbandingan hasil uji CV grafik Kapasitansi Spesifik vs E sampel elektroda a) Ni-G, Ni-G dengan penambahan $\mathrm{NH}_{4} \mathrm{OH}$ b) $0.1 \mathrm{ml}$, c) $0.3 \mathrm{ml}$ dan d) $1 \mathrm{ml}$.

Penggunaan elektrolit netral dari $\mathrm{Na}_{2} \mathrm{SO}_{4}$ pada potensial kerja 0-0.8 V tidak menghasilkan gundukan (hump) seperti yang terlihat pada Gambar 8. Adapun gundukan (hump) merupakan indikator terjadinya reaksi redoks atau efek pseudocapacitance. Adapun yang terjadi dalam pengujian yaitu pembentukan double capacitor. karena diagram $\mathrm{CV}$ yang terbentuk menyerupai persegi panjang. Untuk menghitung kapasitansi spesifik digunakan persamaan:

$$
\mathrm{C}=\frac{\int i d V}{2 w \gamma \Delta E}
$$

Dimana :

$\begin{array}{ll}\mathrm{C} & : \text { Kapasitansi spesifik (Farad/gr) } \\ \mathrm{I} & : \text { Arus (Ampere) } \\ \mathrm{W} & : \text { Massa Elektroda Grafena }(\mathrm{gr}) \\ Y & : \text { Scan Rate }(\mathrm{mV} / \mathrm{s}) \\ \Delta E & : \text { Potential Window (Volt) }\end{array}$

C : Kapasitansi spesifik (Farad/gr)

- Arus (Ampere)

$\Delta E \quad$ : Potential Window (Volt) 
Tabel 4.

Perbandingan hasil kapasitansi spesifik terhadap scan rate dan jumlah doping atom nitrogen

\begin{tabular}{cccr}
\hline \hline Sampel & At \% & $\begin{array}{c}\text { Scan Rate } \\
(\mathbf{V} / \mathbf{s})\end{array}$ & $\begin{array}{c}\text { Kapasitansi } \\
\text { Spesifik (F/g) }\end{array}$ \\
\hline $\mathbf{1}$ & 0 & 0.005 & 152,59 \\
& & 0.01 & 148,42 \\
& & 0.05 & 112,03 \\
$\mathbf{2}$ & \multirow{2}{*}{3.19} & 0.1 & 82,00 \\
& & 0.005 & 171,87 \\
& & 0.01 & 165,73 \\
& & 0.05 & 129,90 \\
$\mathbf{3}$ & \multirow{2}{*}{5.2} & 0.1 & 94,82 \\
& & 0.005 & 208,47 \\
& & 0.01 & 205,62 \\
& & 0.05 & 136,47 \\
$\mathbf{4}$ & & 0.1 & 96,41 \\
& 7.75 & 0.005 & 160,43 \\
& & 0.01 & 158,51 \\
& & 0.05 & 125,09 \\
& & 0.1 & 94,21 \\
\hline \hline
\end{tabular}

Nilai kapasitansi spesifik elektroda nickel foam-N Graphen dengan variasi doping nitrogen mengalami peningkatan nilai kapasitansi hampir di semua scan rate dibanding nilai kapasitansi spesifik Graphene tanpa didoping nitrogen.

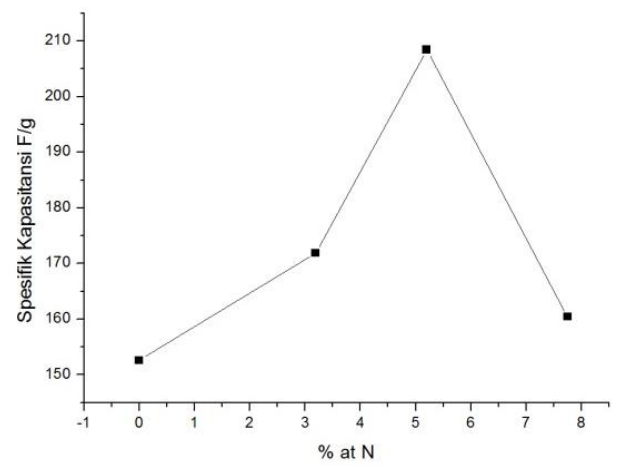

Gambar 9. Perbandingan jumlah doping atom nitrogen terhadap nilai kapasitansi spesifik (scan rate $5 \mathrm{mV} / \mathrm{s}$ ).

Adapun nilai kapasitansi yang dihasilkan dari sampel elektroda nickel foam tersebut dipengaruhi oleh doping nitrogen terhadap graphene. Nilai kapasitansi paling besar terdapat pada graphene dengan penambahan $\mathrm{NH}_{4} \mathrm{OH} 0.3 \mathrm{ml}$ sebesar $208.47 \mathrm{~F} / \mathrm{g}$ (scan rate $5 \mathrm{mV} / \mathrm{s}$ ). Jumlah atom yang terdoping yaitu sebesar 5\%. Dengan penambahan $\mathrm{NH}_{4} \mathrm{OH}$ sebesar $1 \mathrm{ml}$ menghasilkan nilai kapasitansi sebesar 160.437 $\mathrm{F} / \mathrm{g}$. Adapun atom nitrogen yang terdoping yaitu sebesar 7.75\%. Sedangkan dengan penambahan $\mathrm{NH}_{4} \mathrm{OH} 0.1 \mathrm{ml}$ menghasilkan $171.87 \mathrm{~F} / \mathrm{g}$. atom nitrogen yang terdoping sebesar $3.12 \%$.

Graphene dengan doping nitrogen memiliki kapasitansi yang lebih besar [10] hal ini dikarenakan doping nitrogen menyebabkan mikro porous pada graphene meningkatkan wettability pada elektroda/ elektrolit dan dengan doping nitrogen pada graphen dapat meningkatkan binding energy, yang menyebabkan banyak gergerakan ion pada luas permukaan elektoda dan menunjukan kapasitansi yang lebih tinggi. Tetapi pada penambahan doping nitrogen sebesar 7.75\% kapasitansi spesifiknya menurun hal ini dapat disebabkan oleh konduktifitas listriknya yang menurun berdasarkan gambar 10. dengan penambahan nitrogen pada graphen dapat meningkatkan konduktifitas dimana mempercepat mobilitas elektron pada permukaan elektroda tetapi apabila keheteroatomnya besar jumlah atom nitrogen pada graphen dapat mengurangi efisiensi transpor elektronya yang mengakibatkan nilai konduktifitas listrik menurun. Penambahan atom nitrogen yang terlalu banyak dapat membuka band gap yang akan menurunkan sifat elektriknya.[11]

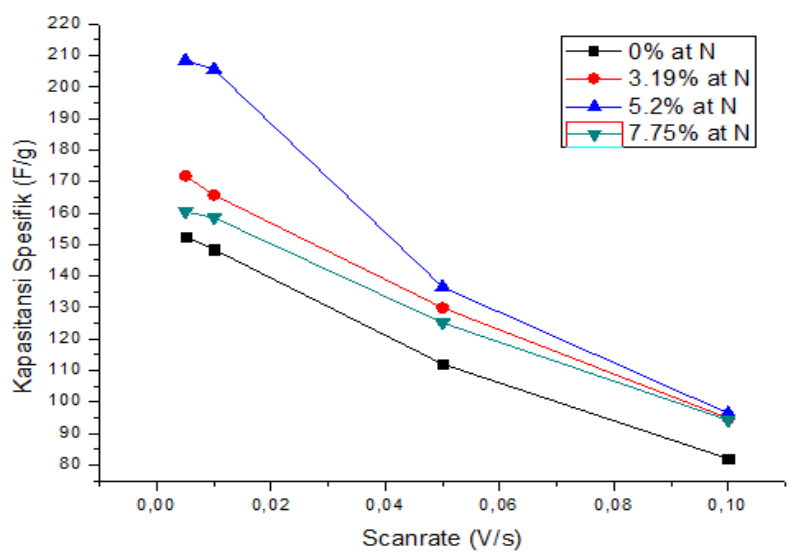

Gambar 10. Grafik Kapasitansi spesifik terhadap scan rate dan Jumlah Doping Nitrogen

Pada Gambar 10 menunjukkan bahwa scan rate semakin tinggi maka nilai kapasitansinya menurun. Hal ini terjadi karena scan rate mempengaruhi laju aliran ion-ion dari elektrolit menuju ke dalam elektroda Ni-graphene. Dengan scan rate yang tinggi maka laju aliran tegangan menjadi cepat, akibatnya waktu yang lebih singkat bagi ion-ion elektrolit untuk berdifusi ke dalam Ni-graphene sehingga membentuk double layer sedikit. Sedangkan pada scan rate yang rendah, laju aliran tegangan menjadi lambat, akibatnya waktu bagi ion-ion elektrolit untuk berdifusi ke dalam Nigraphene lebih lama dan membentuk double layer lebih banyak sehingga nilai kapasitansi Ni-graphene dipengaruhi oleh waktu difusi ion-ion elektrolit [8].

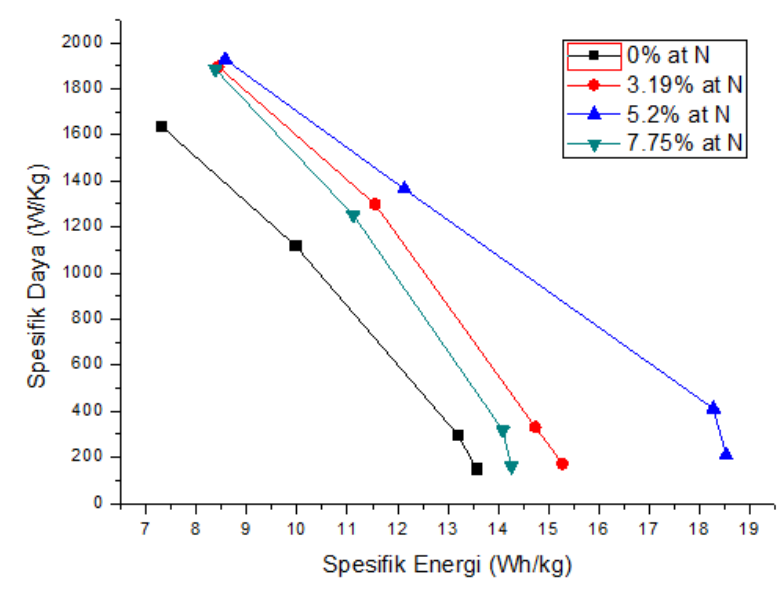

Gambar 11. Grafik perbandingan nilai spesifik daya dan spesifik energi

Nilai kapasitansi hasil dari pengujian CV juga dapat digunakan untuk menentukan nilai energi spesifik dan daya spesifik dengan menggunakan persamaan 3.4 dan 3.5 Hasil Tabel perhitungan spesifik energi dan spesifik daya ditunjukkan oleh Tabel 5 dan Gambar 11. Adapun nilai spesifik energi dan spesifik daya yang paling besar pada scan rate $100 \mathrm{mV} / \mathrm{s}$ dan menurun dengan turunnya nilai scan rate. 
Tabel 5.

Perbandingan hasil Energi spesifik dan daya spesifik terhadap scan rate dan Jumlah Doping Nitrogen

\begin{tabular}{cclrr}
\hline Sampel & \%at N & $\begin{array}{c}\text { Scan } \\
\text { Rate } \\
(\mathbf{V} / \mathbf{s})\end{array}$ & $\begin{array}{c}\text { Spesifik } \\
\text { Energi } \\
(\mathbf{W h} / \mathbf{k g})\end{array}$ & $\begin{array}{c}\text { Spesifik } \\
\text { Daya } \\
(\mathbf{W} / \mathbf{k g})\end{array}$ \\
\hline $\mathbf{1}$ & 0 & 0.005 & 13.56 & 152.60 \\
& & 0.01 & 13.19 & 296.85 \\
& & 0.05 & 9.95 & 1119.86 \\
$\mathbf{2}$ & \multirow{3}{*}{3.19} & 0.1 & 7.28 & 1639.41 \\
& & 0.005 & 15.27 & 171.87 \\
& & 0.05 & 14.73 & 331.46 \\
& & 0.1 & 11.54 & 1298.51 \\
$\mathbf{3}$ & \multirow{3}{*}{5.2} & 0.005 & 8.42 & 1895.81 \\
& & 0.01 & 18.53 & 208.47 \\
& & 0.05 & 18.27 & 411.25 \\
$\mathbf{4}$ & & 0.1 & 12.13 & 1364.23 \\
& 7.75 & 0.005 & 8.57 & 1927.45 \\
& & 0.01 & 14.26 & 160.43 \\
& & 0.05 & 14.09 & 317.03 \\
& & 0.1 & 11.11 & 1250.43 \\
& & 8.37 & 1883.62 \\
\hline \hline
\end{tabular}

Pada gambar 11 menunjukkan tren dari pengaruh jumlah atom nitrogen terhadap nilai kapasitansi spesifik pada elektroda Ni-graphene. Nilai kapasitansi spesifik tertinggi diperoleh pada doping nitrogen $5.2 \%$ at kemudian menurun pada doping nitrogen $3.19 \%$ at dan doping nitrogen $7.75 \%$ at. Penambahan doping nitrogen dapat meningkatkan spesifik kapasitansi seperti pada Tabel 5 tetapi pada penambahan nitrogen $7.75 \%$ spesifik kapasitansinya turun hal ini dapat disebabkan oleh reduksi dari konduktifitas elektrik yang sudah dijelaskan sebelumnya.

Saat atom nitrogen yang memiliki elektron valensi 5 didopingkan ke atom $\mathrm{C}$ yang memiliki elektron valensi 4 akan terjadi aliran elektron dalam sistem akibat adanya elektron yang terdelokalisir. Aliran elektron akibat doping akan mempengaruhi struktur yang dapat dilihat dari analisis pengujian XRD semakin bertambahnya atom nitrogen dalam graphene kristal sizenya akan semakin menurun dan kapasitansi spesifik yang dapat dilihat pada analisis pengujian CV. Sehingga penambahan doping nitrogen berperan penting dalam menentukan sifat kapasitif dari $\mathrm{N}$ graphene[9]. Dari hasil perhitungan daya spesifik dan energy spesifik pada Tabel 5 nampak bahwa doping nitrogen pada graphene memenuhi karakteristik sebagai superkapasitor karena daya spesifik $(\mathrm{W} / \mathrm{Kg}$ ) berada pada rentang $10^{1}$ hingga $10^{6}$ sedangkan energy spesifik berada pada rentang $10^{1}$ hingga 20

\section{KESIMPULAN}

Penambahan doping nitrogen dari $\mathrm{NH}_{4} \mathrm{OH}$ menunjukan adanya perbedaan struktur terhadap grapahene yang didoping dan tidak didoping yaitu pada kristal size pada pengujian XRD, dengan adanya doping maka kristal sizenya menurun. Adanya penambahan doping hidrogen berpengaruh terhadap kapasitansi spesifik graphene dan penambahan nitrogen $5.2 \%$ at merupakan yang paling optimal, karena didapatkan nilai kapasitansi yang paling tinggi sebesar $208.47 \mathrm{~F} / \mathrm{g}$.

\section{UCAPAN TERIMA KASIH}

Penelitian ini tidak bisa berjalan lancar tanpa adanya bantuan dari Ibu Diah Susanti dan Bapak Hanifudin Nurdiansyah selaku dosen pembimbing peneliti yang selalu memberi masukan bagi peneliti dalam menjalankan penelitiannya. Juga bantuan dana dari pemerintah bagi peneliti untuk bisa menjalankan penelitian ini dengan baik.

\section{DAFTAR PUSTAKA}

[1] Singh, V., Joung, D., Zhai, L., Das, S., Khondaker, S. I., \& Seal, S 2011. "Graphene based materials: past, present and future". Progress in materials science, 56(8), 1178-1271.

[2] Panchakarla, L. S., Subrahmanyam, K. S., Saha, S. K., Govindaraj, A., Krishnamurthy, H. R., Waghmare, U. V., \& Rao, C. N. R. 2009. "Synthesis, structure and properties of boron and nitrogen doped graphene". arXiv preprint arXiv:0902.3077.

[3] Suresh, B. S., Elavarasan, A., \& Sathish, M. 2016. "High performance supercapacitor using N-doped graphene prepared via supercritical fluid processing with an oxime nitrogen source". Electrochimica Acta, 200, 37-45

[4] Nurdiansyah, H. dan Susanti, D. 2014. "Pengaruh Variasi Temperatur Hidrotermal dan Waktu Ultrasonikasi Terhadap Nilai Kapasitansi Elektroda Electric Double Layer Capacitor (EDLC) dari material grafena". Thesis S2 Teknik Material dan Metalurgi ITS.

[5] Ting, L. T., Lai, W. H., Lü, Q. F., \& Yu, Y. 2015. "Porous nitrogendoped graphene/carbon nanotubes composite with an enhanced supercapacitor performance". Electrochimica Acta, 178, 517-524.

[6] Ilhami, M., Susanti, D. 2014. "Pengaruh massa Zn dan temperatur hydrothermal terhadap struktur dan sifat elektrik material Graphene". JURNAL TEKNIK POMITS Vol. 3, No. 2, (2014) ISSN: 2337 3539.

[7] Yu. F., Lo, S. T., Lin, J. C., Zhang, W., Lu, J. Y., Liu, F. H., \& Li, L. J. 2013. "Nitrogen-doped graphene sheets grown by chemical vapor deposition: Synthesis and influence of nitrogen impurities on carrier transport". ACS nano, 7(8), 6522-6532.

[8] Conway, B.E. 1999. Electrochemical Supercapacitors. Scientific Fundamentals and Technological Applications. New York, U.S.A: Kluwer Academics/Plenum Publishers.

[9] Geng, D., Yang, S., Zhang, Y., Yang, J., Liu, J., Li, R., \& Knights, S. 2011. "Nitrogen doping effects on the structure of graphene". Applied Surface Science, 257(21), 9193-9198.

[10] Gong, Y., Li, D., Fu, Q., \& Pan, C. 2015. "Influence of graphene microstructures on electrochemical performance for supercapacitors". Progress in Natural Science: Materials International, 25(5), 379-385.

[11] Mei, X., Xiuqing, M., Fengmin Wu. 2015. "Hydrothermal method for the production of reduced Graphene oxide". Physica E 68: 81-86.

[12] Zhang, X. W., Yang, G. W. 2009. "Novel Band Structures and Transport Properties from Graphene Nanoribbons with Armchair Edges". J. Phys, Chem. C 113, 4662-4668. 